\title{
Additional illumination, artificial pollination and use of pollen from additionally illumi- nated plants in early-tomato growing ${ }^{1}$
}

\author{
K. VERKERK
}

Laboratorium voor Tuinbouwplantenteelt, Landbouwhogeschool, Wageningen, Netherlands

\section{Contents}

Summary

1. Introduction

2. Description of experiments

3. Experiment I

4. Experiment II

5. Discussion

6. Conclusions

References

\section{Summary}

In the determinate tomato variety Dwarf Gem the effects of additional illumination, artificial pollination, two extra leaves on some lateral shoots and the use of good pollen from flowers of illuminated plants were studied early in spring in the greenhouse. The additional illumination and the artificial pollination alone, and particularly in combination, accelerated the yield considerably. The effect of the extra leaves was variable. Viable pollen from illuminated plants gave good results on flowers of not illuminated plants: The numbers of seed per fruit and hence the fruit size and earliness were better than with artificial pollination.

\section{Introduction}

Most of the tomato varieties used in the Netherlands are of the indeterminate type and do not stop their terminal growth with a truss. These varieties mostly have three leaves in between two successive trusses. The self-topping or determinate varieties, however, often have less leaves in between each pair of trusses. The variety Dwart Gem used in this work has one leaf only in between two trusses. This variety is vegetatively not so strong, but flowers are formed relatively easily. When this variety is grown early in the spring, with deficiency of natural light, it could be useful to enlarge the leaf surface for assimilation by maintaining some lateral shoots with two or three leaves. Furthermore, a good effect of additional artificial illumination during

1 Also published as: Publication 263, Laboratorium voor Tuinbouwplantenteelt, Landbouwhogeschool, Wageningen, Netherlands.

Received for publication 24th December, 1964. 
the darkest winter period is to be expected. To receive a good fruit growth extra attention has to be paid to pollination. Good pollen, however, is scarce in early spring. In experiment $I$ the idea was to use stored pollen from the preceding summer, but this became a failure. So in experiment II pollen from illuminated plants was used on flowers of plants grown without additional light.

\section{Description of experiments}

Ge ne ra 1 - The plants were planted out in pots with a diameter of $30 \mathrm{~cm}$. These pots were placed on the soil in the benches, so that most of the roots stayed in the pots. The distances between plants were $40 \times 50 \mathrm{~cm}$. The plants were topped after $3-4$ trusses, $15-20$ fruits being ideal.

Additiona 1 illum in ation - To have good plants early in January, sowing was done late in October or early in November. Directly after germination the additional illumination of 16 hours per day with fluorescent lamps, also during daytime, was started. The installed power of $120 \mathrm{~W} / \mathrm{m}^{2}$ provided the plants during their early growth with about twice the light energy they would have had without illumination, resulting in sturdy and well-developed plants in the beginning of January (VERKERK, 1962). After planting in the pots on 8th January the plants were divided into two groups, one receiving normal daylight in the greenhouse $(-L)$ and the other remaining under additional light until mid-March $(+\mathrm{L})$, the latter group receiving about $50 \%$ more light energy than the former plants.

Extra leaves - Normally the lateral shoots of the tomato plants are pinched out at an early stage (-E). In other plants lateral shoots with two or three leaves were kept in the axils of the third to fifth leafs $(+E)$.

Pollination - Especially in early spring a good pollination is very important. As a check no special pollination was given $(-V)$, while three times a week vibration with the artificial bee $(+V)$ was used as a treatment (COTTRELL-Dormer, 1945; WellensieK, 1948 ; VeRKerK, 1957).

\section{Experiment I}

P 1 a n - The experiment consisted of 6 replicates of 8 treatments: -

$$
\begin{array}{llllll}
-\mathrm{L} & -\mathrm{E} & -\mathrm{V} & +\mathrm{L} & -\mathrm{E} & -\mathrm{V} \\
-\mathrm{L} & -\mathrm{E} & +\mathrm{V} & +\mathrm{L} & -\mathrm{E} & +\mathrm{V} \\
-\mathrm{L} & +\mathrm{E} & -\mathrm{V} & +\mathrm{L} & +\mathrm{E} & -\mathrm{V} \\
-\mathrm{L} & +\mathrm{E} & +\mathrm{V} & +\mathrm{L} & +\mathrm{E} & +\mathrm{V}
\end{array}
$$

First anthesis in the $+\mathrm{L}$ group was on 4 th, in the $-L$ group on 22 nd February.

Fifteen fruits 1 arger than $4 \mathrm{~mm}$ was taken as a criterion to stop the artificial pollination and to get a preliminary impression of the effect on earliness of the different treatments. The number of days after 15th February required for these 15 fruits larger than $4 \mathrm{~mm}$ to be formed, is given in TABLE 1. This table demonstrates that $+\mathrm{L}$ is very much earlier than $-\mathrm{L}$, which is not so astonishing after all the extra light energy the $+\mathrm{L}$ plants received. The effect of $+\mathrm{E}$ on earliness is slight. The effect of artificial pollination, (+V), however, may be enormous. Combined with $+\mathrm{L}$ it is larger than with $-\mathrm{L}$ and with $+\mathrm{E}$ larger than with $-\mathrm{E}$. The 
ADDITIONAL ILlUMination, ARTIFICIAL POLlination AND USE OF POLLEN FROM ...

TABLE 1. Numbers of days after 15 th February required for 15 fruits larger than $4 \mathrm{~mm}$ to be formed

\begin{tabular}{|c|c|c|c|c|c|c|}
\hline \multicolumn{3}{|c|}{-L 39} & \multicolumn{4}{|c|}{$+\mathrm{L} 16$} \\
\hline -E 39 & & & & & & \\
\hline$-V 41+V 37$ & $-\mathrm{V} 42$ & $+\mathrm{V} 34$ & $-\mathrm{V} 20$ & +V 14 & $-V 26$ & $+V 3$ \\
\hline
\end{tabular}

combination $+\mathrm{L}+\mathrm{E}+\mathrm{V}$ is 11 days earlier than the next treatment $+\mathrm{L}-\mathrm{E}+\mathrm{V}$ and even 38 days earlier than the control $-\mathrm{L}-\mathrm{E}-\mathrm{V}$.

Fruit yield - The first ripe fruit was picked in the $+L$ group on 27th April, in the - $\mathrm{L}$ group on 6th May, which is rather late. The cumulative yield of the fruit weight per plant per treatment is given in FIG. 1. Most striking is the effect of the

Frg. 1. Cumulative yields of plants with different treatments

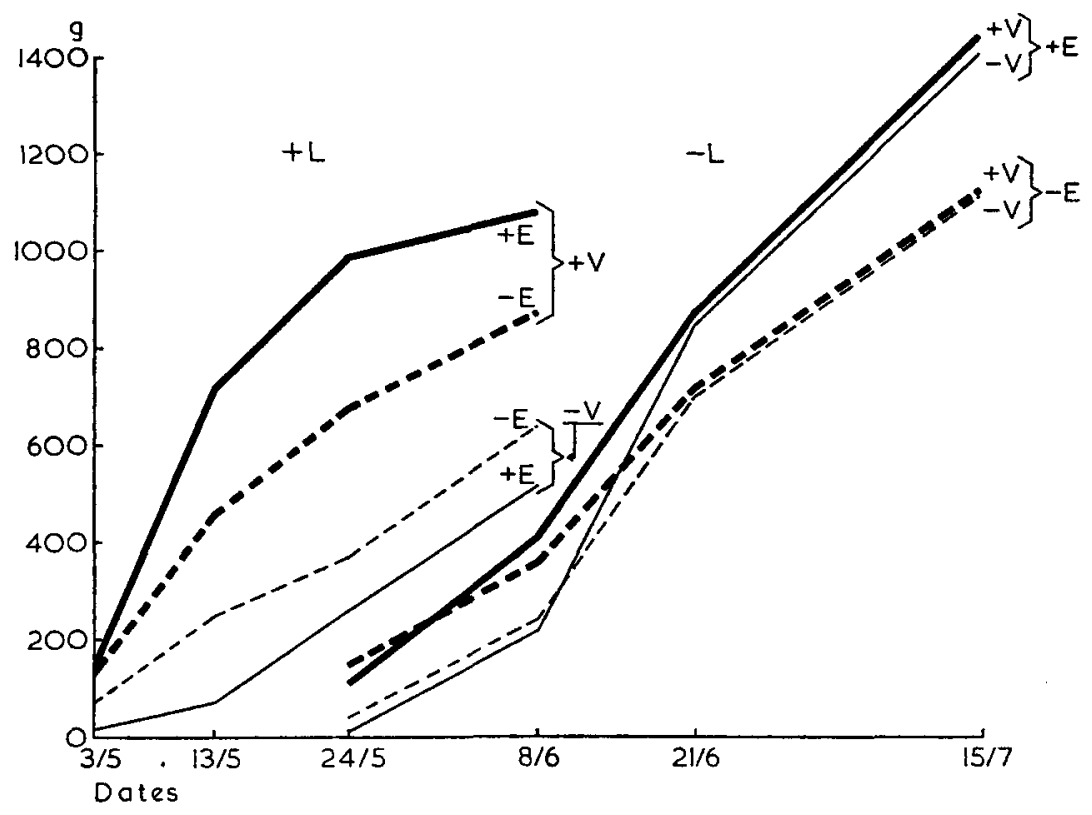

additional illumination. However, the total yields of the $+\mathrm{L}$ group remains much lower than that of the corresponding $-\mathrm{L}$ group. The effects of $+\mathrm{E}$ and $+\mathrm{V}$ are so different in the $+\mathrm{L}$ and $-\mathrm{L}$ groups that they have to be treated separately.

In the $+\mathbf{L}$ groups artificial pollination is the most important factor, the extra leaf playing only a secondary role. With artificial pollination $(+V)$ involving many growing seeds, the young fruits need a large supply of assimilates and the extra leaf will act positively. In the $-V$ group seeds are relatively scarce and the extra leaf has a retarding effect. A positive interaction exists between extra leaf and artificial pollination.

The - $\mathrm{L}$ group, in which the fruits mature much later than in the $+\mathbf{L}$ group, shows the same effects only during the first time of the harvest period. Afterwards, the 
extra leaf is the most important, the artificial pollination losing its importance. The effect of these factors is reversed in June, which means that the artificial pollination lost most of its importance in April.

The expectation of earliness, to be derived from TABLE 1, is in good agreement with the points for $300 \mathrm{~g}$ in the lines in FIG. 1.

The mean numbers of fruits larger than $4 \mathrm{~cm}$ are given in TABLe 2.

TABLE 2. Numbers of ripe fruits per plant larger than $4 \mathrm{~cm}$

\begin{tabular}{|c|c|c|c|c|c|}
\hline \multicolumn{2}{|c|}{$-\mathrm{L} 15$} & \multicolumn{4}{|c|}{ +L 9} \\
\hline -E 14 & +E 17 & & & & \\
\hline$-V 11+V 16$ & $-\mathrm{V} 15+\mathrm{V} 18$ & $-V 5$ & $+\mathrm{V} 12$ & $-\sqrt{3}$ & $+V 16$ \\
\hline
\end{tabular}

The $+\mathrm{L}$ plants, having a lower yield in weight than the $-\mathrm{L}$ plants, also gave a smaller number of fruits. Artificial pollination acted favourably in all cases, but a strong positive interaction with additional illumination exists: in the $-\mathrm{L}$ groups a relatively slight effect, in the $+\mathrm{L}$ groups a very strong effect of $+\mathrm{V}$ is found.

$\mathrm{Sh}$ a pe of fruit - Especially in the beginning of the harvest period the $+\mathrm{L}$ plants had relatively good round fruits, while the $-\mathbf{L}$ plants produced many irregular fruits (cf. FIG. 2). On the $+L$ plants the additional light energy makes the ovules much more regular than those of the $-\mathrm{L}$ plants which have an irregular style too.

\section{Experiment II}

P 1 a n - Experiment II was more extensive than experiment I. Pollen collected during the artificial pollination of the $+\mathrm{L}$ plants was utilized with some of the $-\mathrm{L}$ plants by dipping the styles in $(+P)$. In the beginning it was necessary to remove the stamens, but later on the style was long enough to be immersed into the pollen without castration. The quantity of pollen brought on the style was visible by the naked eye. A combination of $+\mathrm{V}$ and $+P$ was also present. The number of treatments was increased considerably compared with experiment I: -

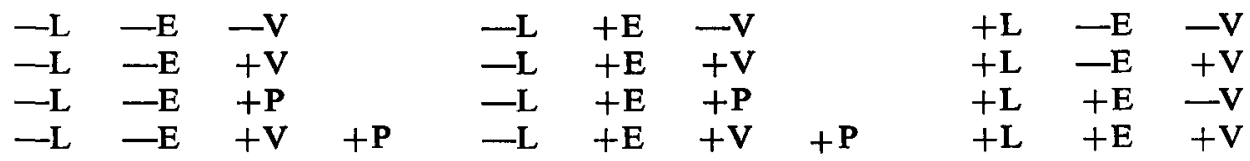

There were 4 replicates and 4 plants per treatment.

First anthesis - Soon after 8th January a distinct difference between $+L$ and $-\mathrm{L}$ plants could be seen. The $+\mathbf{L}$ plants grew faster and had dark green leaves. The young leaves of the $-\mathrm{L}$ plants had a light green colour. First anthesis in this experiment took place on 19th January in the $+\mathrm{L}$ group and on 29th January in the $-\mathbf{L}$ group. In the $+\mathbf{L}$ group all flower buds developed well, in the $-\mathbf{L}$ groups a few flower buds of the lower trusses did not open properly.

Fruit s e t - Pollination is very important for the first growth of the ovules, because this growth is closely correlated with the number of fertilized egg cells in the ovules. Good pollen could be harvested directly at the beginning of flowering in the $+\mathrm{L}$ plants and this was utilized for pollination of some of the $-L$ plants. The $-\mathrm{L}$ plants themselves did not produce a quantity of pollen of any importance 
FIG. 2

Shape of fruits of $+\mathrm{L}$ plants (upper two trusses) and of $-\mathrm{L}$ plants (lower two trusses)

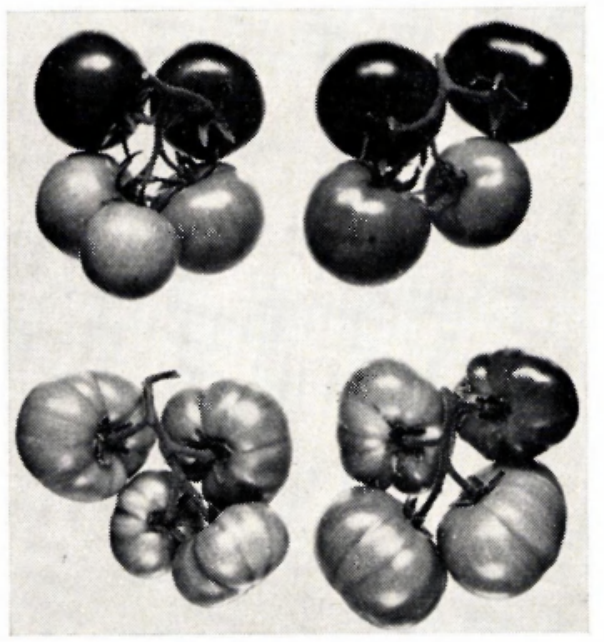



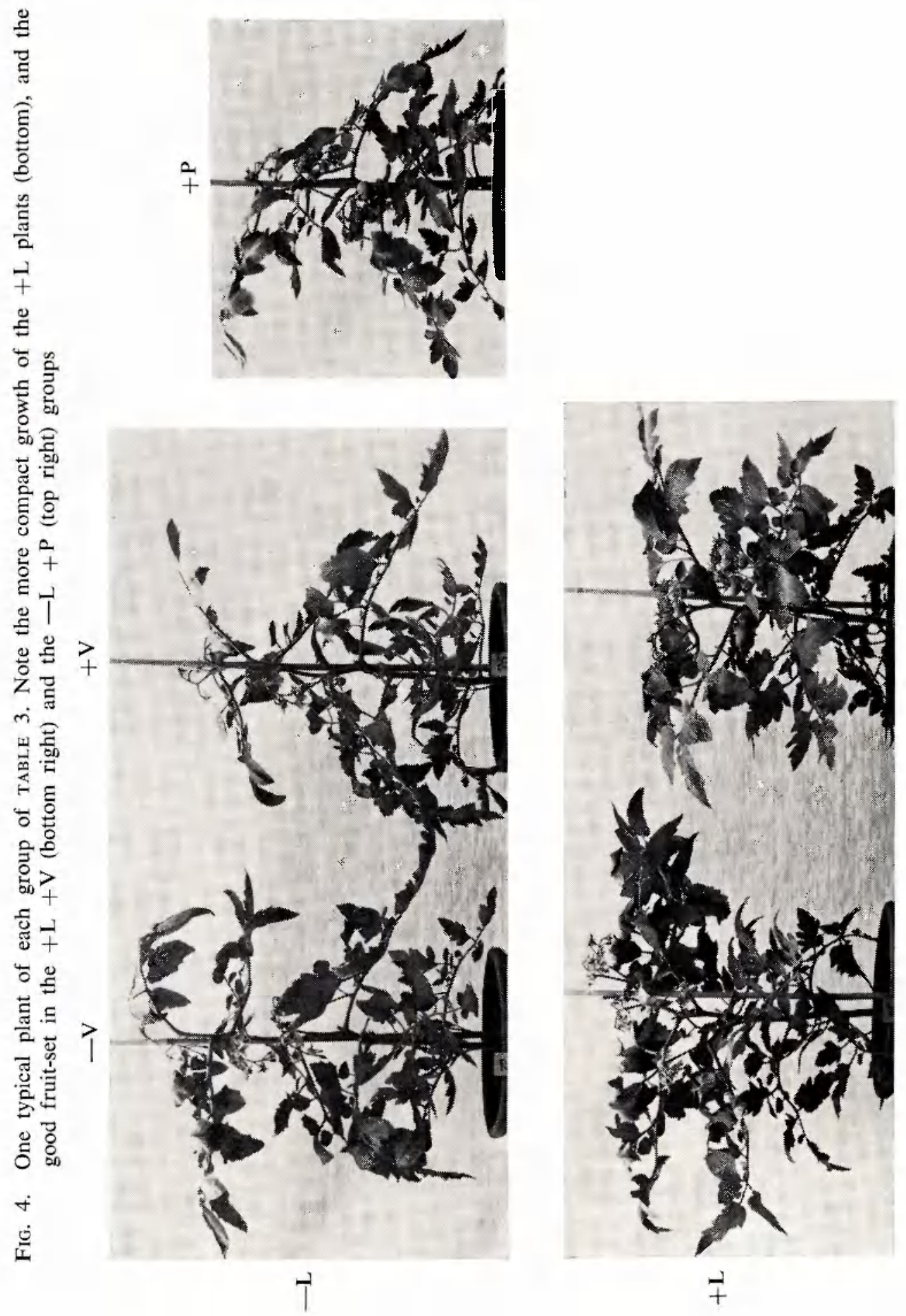
before 18th February. Some thirty flowers of all treatments were labelled on 13th, 20 th and 25th February to determine the growth of the ovary after 5 to 24 days. As soon as the ovary was larger than it was at anthesis, it was classified as "grown". The percentages "grown" in each treatment in connection with time are given in FIG. 3 where $+\mathrm{E}$ and $-\mathrm{E}$ treatments are combined. At the left where each line

Fig. 3. Ovary growth with different treatments

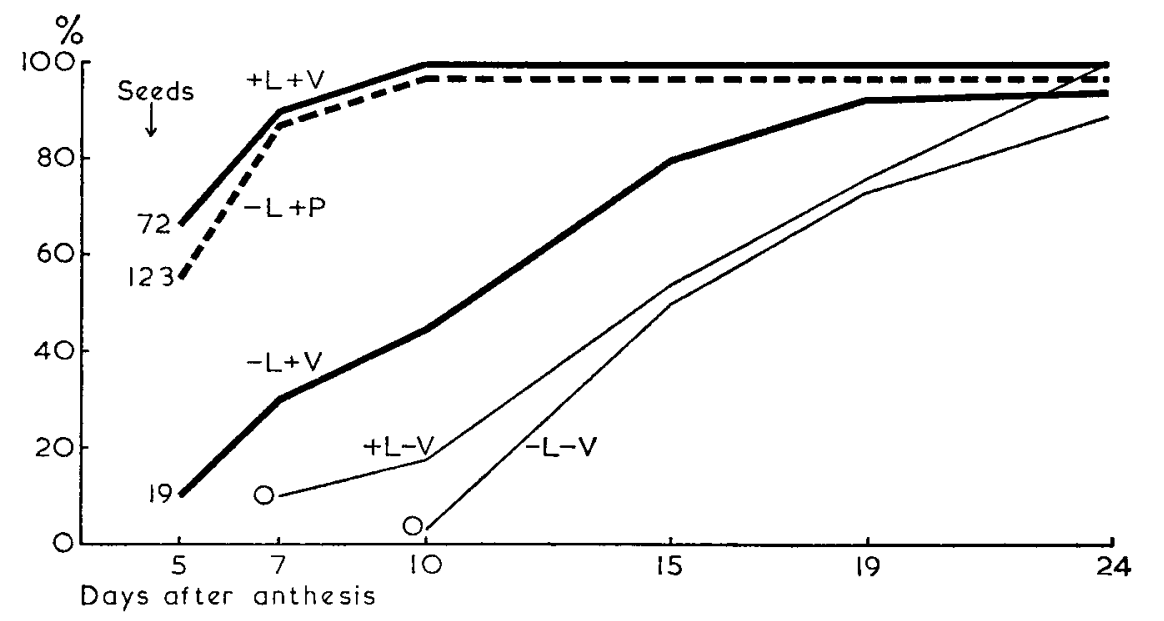

begins the number of seeds in the mature fruits at harvest time is shown. Additional illumination combined with artificial pollination shows the fastest growth of the ovary, which means good pollination of strong plants. Approximately the same growth, but with more seeds, is found in the $-\mathrm{L}$ plants pollinated with the good pollen of the $+\mathrm{L}$ plants $(-\mathrm{L}+\mathrm{P})$. Artificial pollination $(+\mathrm{V})$ of the $-\mathrm{L}$ plants was not very effective, because good pollen was scarce in the - L plants at that time of the year. In the unpollinated groups wherein the ovaries contain no seeds, ovary growth was the slowest: three weeks had to elapse before the growth of the ovary was visible compared with only one week for the groups receiving good pollen (see FIG. 3).

The number of $\mathrm{fruits}$ larger tha $4 \mathrm{~mm}$ was counted thrice. The counting on 5th March gave clear-cut results (TABLE 3), but on 25 th of that month all differences had disappeared.

TABLE 3. Number of fruits larger than $4 \mathrm{~mm}$ on 5 th March

\begin{tabular}{rrrr} 
& $-\mathrm{V}$ & $+\mathrm{V}$ & $+\mathrm{P}$ \\
$-\mathrm{L}$ & 0.3 & 4.8 & 9.5 \\
$+\mathrm{L}$ & 2.2 & 16.6 & \\
\hline
\end{tabular}

The order of the figures in TABLE 3 is the same as in FIG. 3, except that $-\mathbf{L}+\mathbf{P}$ lags behind $+\mathrm{L}+\mathrm{V}$, because the $-\mathrm{L}$ plants receive far less energy than the $+\mathrm{L}$ plants. The combination $+\mathrm{V}+\mathrm{P}$ does not show any difference with $+\mathrm{P}$ alone so they were combined. FIG. 4 shows a typical plant of each group of TABLE 3.

F r u it y i e Id - Starting on 2nd April until 31st May fruits were picked three times a week. Fruitshape being rather irregular with 3 to 4 loculed fruits, is strongly effected 
by the intensity of pollination; good pollination makes the fruits much more regular. Extra leaves did not show a reliable difference in yield as compared with no extra leaves, though a small tendency exists for yield retardation by the extra leaves. In FIG. 5 which shows the cumulative yields, $+\mathrm{E}$ and $-\mathrm{E}$ are combined. In this figure

FIG. 5. Cumulative yields of plants with different treatments

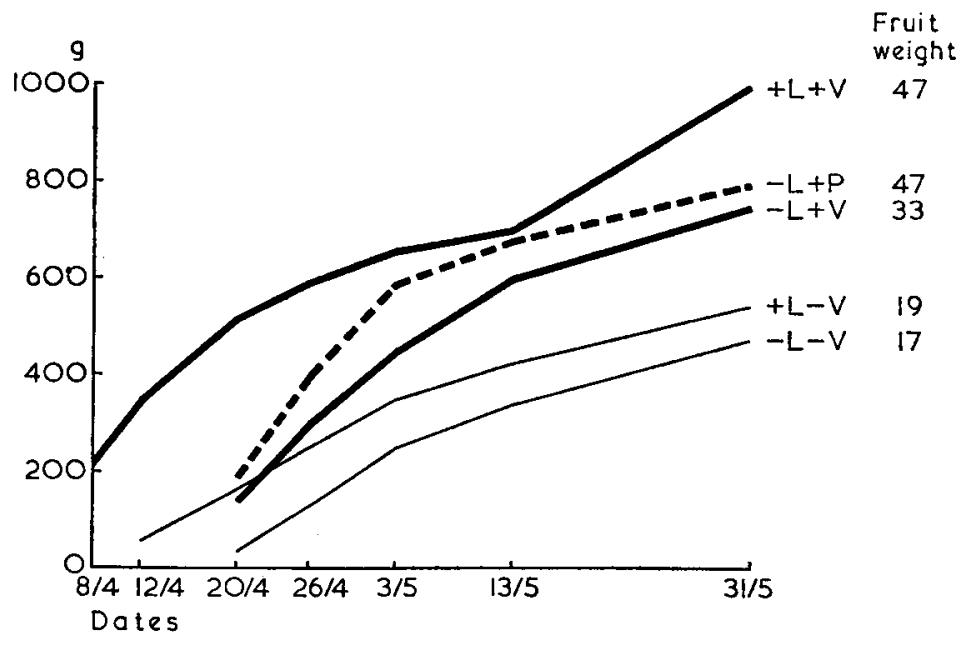

mean fruit weights are given at the end of each yield line; it is shown that the higher yields partly are the result of heavier fruits. Earliness is closely correlated with the number of fruits larger than $4 \mathrm{~mm}$ on 5th March (see TABLE 3). The earliest treatment, $+\mathrm{L}+\mathrm{V}$, shows an increase in yield after 13th March which coincides approximately with the removal of the lamps. Additional illumination again shows an earlier yield than $-\mathrm{L},+\mathrm{V}$ a much earlier yield than $-\mathrm{V}$, but the combination of $+\mathrm{L}+\mathrm{V}$ is by far the earliest. Differences between $-\mathrm{L}+\mathrm{P}$ and $-\mathrm{L}+\mathrm{V}$ were neither reliable on 20th April nor on 31st May, but they were reliable on the other three dates mentioned (FIG. 5).

Number of seeds in fruits of $50 \mathrm{~g}$ and weight of the axillary $\mathrm{shoots}$ - The number of seeds in fruits of $50 \mathrm{~g}$ gives an idea of the energy it takes the plants to produce these fruits. In the $+\mathrm{E}$ treatments this number of seeds is a little higher than in the corresponding $-\mathrm{E}$ treatments; the extra leaves can be considered as competing with the growing fruits. The same competition is shown in TABLE 4, where the fresh weights of the axillary shoots are negatively correlated with the numbers of seeds in fruits of $50 \mathrm{~g}$. The earliest group $(+\mathrm{L}+\mathrm{V})$ needs the greatest number of seeds to form a fruit of $50 \mathrm{~g}$ and has the smallest axillary shoots. The

TABle 4. Number of seeds in fruits of $50 \mathrm{~g}$ (1st figure) and fresh weight of axillary shoots of $+E$ in $g$ (2nd figure) at the end of the harvest period

\begin{tabular}{|c|c|c|c|}
\hline & $-\mathbf{V}$ & $+\mathrm{V}$ & $+P$ \\
\hline $\begin{array}{l}-\mathrm{L} \\
+\mathrm{L}\end{array}$ & $\begin{array}{l}-110 \\
-139\end{array}$ & $\begin{array}{r}43-73 \\
108-35\end{array}$ & $96-50$ \\
\hline
\end{tabular}


later the yield, the lower the number of seeds required for the formation of $50 \mathrm{~g}$ of fruit and the larger the axillary shoots are.

$\mathrm{Number}$ of seeds and mean fruit weight was determined of 14 fruits produced from 13th to 25th February. The means of $+\mathrm{E}$ and $-\mathrm{E}$ treatments are given in TABLE 5. In February no good fruits can be formed without artificial pol-

TABle 5. Number of seeds (1st figure) and fruit weight (2nd figure) of fruits produced from 13th and 25th February

\begin{tabular}{cccc} 
& $-\mathrm{V}$ & $+\mathrm{V}$ & $+\mathrm{P}$ \\
\cline { 2 - 3 } $\mathrm{L}$ & $0-16$ & $19-33$ & $123-61$ \\
$\mathrm{~L}$ & $0-14$ & $72-41$ & \\
\hline
\end{tabular}

lination $(-\mathrm{V})$. Artificial pollination $(+\mathrm{V})$ is of little use in $-\mathrm{L}$, because plants with deficiency of light do not form an abundance of good pollen. The plants with additional light, however, receiving enough light energy form flowers with good pollen and the pollination with the artificial bee is very effective. By far the greatest number of seeds are formed in the $-\mathrm{L}+\mathrm{P}$ plants after dipping the style of the flowers into pollen from the $+\mathrm{L}$ plants, which means that an abundant pollination with good pollen existed. These fruits are also the largest.

\section{Discussion}

Introduction - First the individual effects of additional illumination, extra leaves, artificial pollination and dipping the style in good pollen will be dealt with, followed by a discussion on their interrelations.

Additional illumination until mid-March produces a yield which is one to four weeks earlier for the first $300 \mathrm{~g}$ per plant. The effect of the additional illumination will be partly the result of a slightly higher temperature. It is known that higher temperatures give a faster growth and an earlier yield compared with lower temperatures (VERKERK, 1955, 1964). The increase in growth of the $+\mathrm{L}+\mathrm{V}$ plants in experiment II (see FIG. 5) at the removal of the lamps shows that in March the lamps have an adverse effect on the plants rather than otherwise. The same trend was found earlier in additional illumination after planting in the greenhouse (VERKERK and WellensieK, 1950). The final yield of the - $\mathrm{L}$ plants of experiment $\mathrm{I}$ is much higher than the yield of all other plants. This could be caused by the facts that the yield of these - L plants is up to 5 weeks later than in the other groups and that the natural conditions are much more favourable then.

The effect of the extra leaves was not identical in both experiments. In experiment $\mathrm{I}$ the $+\mathrm{L}$ groups showed a clear interaction between the extra leaves and the artificial pollination. Together with pollination $(+V)$ the extra leaves have a positive, without pollination ( $-V$ ) a negative effect (FIG. 1). In the last case the growth of the extra leaves is relatively strong. The importance of an intens pollination in the case of extra leaves was shown earlier (VERKERK, 1963). In the $-\mathrm{L}$ groups the same tendency is found in the beginning of the harvest period, but later on the effect of the extra leaves on these plants with only one leaf in between two successive trusses increases, while that of the artificial pollination decreases relatively with time, because the natural pollination improves. This results in a slight difference between $+\mathrm{V}$ and $-\mathrm{V}$ and a greater difference between $+\mathrm{E}$ and $-\mathrm{E}$. 
The conclusion is that in the early $+\mathrm{L}$ groups artificial pollination is the most important factor, as the natural pollination is very poor. The effect of the extra leaves is positive when combined with $+\mathrm{V}$. They contribute to the production of the assimilates for fruit growth. Without artificial pollination $(-V)$, however, the effect is opposite: the fruits with only a relatively small number of seeds have less energy to concentrate assimilates than in the $+\mathrm{V}$ groups and the yield is lower.

In experiment II the effect of the extra leaves is quite different. In nearly all cases there is a tendency for the extra leaves to slightly retard the yield, but no significant differences were found. TABLE 4 showed that the axillary shoots decrease in length as a greater number of growing seeds are required to form a fruit of $50 \mathrm{~g}$. The great number of seeds concentrate relatively much nutritive substances, the fruits grow rapidly and the axillary shoots slowly. This competition between leaf growth and fruit growth, between vegetative and generative growth has already been discussed before (VERKERK, 1955, 1963).

Differences in effects of extra leaves as found in experiment I and II, positive in one case and not positive or even negative in others, are known from literature (VERKERK, 1963).

Artificial pollination accelerates the harvest of the first $300 \mathrm{~g}$ per plant with one to three weeks, mostly in combination with additional illumination (VERKERK and WellensIEK, 1950; VerKeRK, 1957). +P only accelerates the harvest three days as compared with its check $-\mathrm{L}+\mathrm{V}$. However, the larger amount of seeds per fruit giving larger fruits (see TABLE 5) accelerates the harvest 10 days in comparison with $600 \mathrm{~g}$ per plant.

An estimate of relative e a rliness in an early stage of fruit growth was made in different ways in experiments I and II. In experiment I, the date on which 15 fruits larger than $4 \mathrm{~mm}$ were present was taken as a criterion, in experiment II it was the number of fruits larger than $4 \mathrm{~mm}$ on a certain date. In both cases the results were compared with the relative earliness of the first $300 \mathrm{~g}$ per plant (TABLE 6).

TABLE 6. Estimate of relative earliness at the small-fruit stage

\begin{tabular}{|c|c|c|c|c|c|}
\hline \multicolumn{3}{|c|}{ Experiment I } & \multicolumn{3}{|c|}{ Experiment II } \\
\hline Treatment & $\begin{array}{l}15 \text { fruits }>4 \mathrm{~mm} \\
\text { in days after } \\
15 \text { th Feb. }\end{array}$ & $\begin{array}{l}300 \mathrm{~g} / \text { plant in } \\
\text { days after } \\
\text { 30th April }\end{array}$ & Treatment & $\begin{array}{l}\text { No. of fruits } \\
74 \mathrm{~mm} \text { on } \\
5 \text { th March }\end{array}$ & $\begin{array}{c}300 \mathrm{~g} / \text { plant in } \\
\text { days after } \\
\text { 31st March }\end{array}$ \\
\hline$+\mathrm{L}+\mathrm{E}+\mathrm{V}$ & 3 & $\begin{array}{l}5 \\
8\end{array}$ & $+\mathbf{L}+\mathbf{V}$ & 16.6 & 11 \\
\hline$+\mathrm{L}-\mathrm{E}+\mathrm{V}$ & 14 & 8 & & & \\
\hline $\begin{array}{l}+\mathrm{L}-\mathrm{E}-\mathrm{V} \\
+\mathrm{L}+\mathrm{E}-\mathrm{V}\end{array}$ & 20 & 18 & $-\mathbf{L}+\mathbf{P}$ & 9.5 & 23 \\
\hline$+\mathrm{L}+\mathrm{E}-\mathrm{V}$ & 26 & 27 & $-L+V$ & 4.8 & 26 \\
\hline$-\mathrm{L}+\mathrm{E}+\mathrm{V}$ & 34 & 34 & & & \\
\hline$-\bar{L}-\bar{E}+\mathrm{V}$ & 37 & 36 & $+\mathrm{L}-\mathrm{V}$ & 2.2 & 30 \\
\hline$-\mathrm{L}-\mathrm{E}-\mathrm{V}$ & 41 & 42 & & & \\
\hline$-\mathrm{L}+\mathrm{E}-\mathrm{V}$ & 42 & 42 & $-\mathbf{L}-\mathbf{V}$ & 0.3 & 38 \\
\hline
\end{tabular}

Both methods give a fairly good estimate of the relative earliness of the yields in the different treatments.

Fruit-set, number of seeds and mean fruit weight after artificial pollination - Unfortunately, in experiment $I$ it was impossible to utilize stored viable pollen for pollination of flowers of plants receiving the natural greenhouse light in early spring. In experiment II, however, abundant pollen from 
illuminated plants could be used for the pollination of other plants. Between 13th and 25th February the $-\mathrm{L}$ plants did not have much good pollen themselves, for even after vibration with the artificial bee only 19 seeds per fruit were formed (FIG. 3). With the use of good pollen this was increased to 123 seeds per fruit, which is even much more than the 72 seeds on the $+\mathrm{L}$ plants after artificial pollination. This is presumably the main effect of dipping the style into the pollen compared with just vibrating. The number of seeds per fruit showed its effect in the fast growth of the ovules (FIG. 3) and in the fruit weights (TABLE 5). The more seeds per fruit, the larger fruits (VERKERK, 1957).

Earlier research has shown that tomato pollen mostly can be mixed with an inactive powder without losing much of its effect (VERKERK, 1957).

\section{Conclusions}

1. Both additional illumination and artificial pollination separately, and particularly in combination, have an accelerating effect on yield.

2. The use of good pollen from additionally illuminated plants on plants under normal greenhouse conditions early in spring results in a good growth of ovules and fruits to normal size.

3. The effect of extra leaves on axillary shoots in the variety Dwarf Gem early in spring cannot be predicted.

4. It is advisable to assess the relative earliness of different treatments at a smallfruit stage.

\section{ACKNOWLEDGEMENT}

Only by the great enthusiasm and careful observations of Ir. P. KLEYBURG the necessary figures for this study could be collected.

\section{REFERENCES}

COTTRELl-Dormer, $\mathbf{W}$.

VERKERK, K.

SIEK and S. J. WELLEN-

WELLENSIEK, S. J.
1945 An electric pollinator for tomatoes. Queenst. J. Agr. Sci. 2, 157-169.

1955 Temperature, light and the tomato. Meded. Landb.hogesch., Wageningen. 55, 175-224.

1957 The pollination of tomatoes. Neth. J. agric. Sci. 5, 37-54.

1962 Aanvullende belichting van jonge tomaten in 1959/1960 en $1960 / 1961$. (Additional illumination of young tomato plants in 1950/60 and 1960/61). Meded. Dir. Tuinb. 25, 106-113, 137.

1963 Interaction of pollination and number of leaves in the tomato. Neth. J. agric. Sci. 11, 188-197.

1964 Additional illumination before and temperature after planting of early tomatoes. Neth. J. agric. Sci. 12, 57-68.

1950 De invloed van kunstmatige bestuiving en belichting bij tomaten. (The influence of artificial pollination and illumination of tomatoes). Meded. Dir. Tuinb. 13, 620-628.

1948 Een kunstmatige bloembestuiver. (An artificial pollinator). Meded. Dir. Tuinb. 11, 101-104. 